\title{
Chemical, Morphological Characterizations of Ririwai Biotite and Determination of Yield Point of its Weighting Agent Application in Drilling Mud
}

\author{
N. Salahudeen*, U. Mohammed, M. N. Yahya \\ Department of Chemical and Petroleum Engineering, Bayero University, Kano, NIGERIA.
}

\begin{abstract}
Chemical, morphological characterizations and drilling mud yield point impact of Ririwai biotite have been investigated and reported in this work. Local Ririwai biotite mined in Doguwa Local Government Area of Kano State was used as a weighting agent in drilling mud formulation. Scanning Electron Microscopy (SEM) characterization, X-ray Diffraction (XRD) and Electron Dispersion X-ray (EDX) analysis of the Ririwai biotite were carried out. Water-based drilling mud was prepared using commercial bentonite according to the API 13A Standard. Effect of gradual addition of Ririwai weighting agent; $0-100 \mathrm{wt} \%$, on the yield point of the formulated drilling mud was studied. XRD analysis showed that the dominant mineral phase in the material was biotite. Morphological analysis carried out showed that the Ririwai biotite had a sheet-like morphology while the commercial bentonite had clumpy morphology. The estimated average particle sizes were 60 and $25 \mu \mathrm{m}$ for the Ririwai biotite and commercial bentonite, respectively. EDX analysis showed that silica-alumina ratio of the Ririwai biotite was 9.3 while that of the commercial bentonite was 1.58. The optimum yield point of the formulated drilling mud was $2.0 \mathrm{lb} / 100$ $\mathrm{ft}^{2}$ corresponding to formulation having $0-30 \mathrm{wt} \%$ weighting agent composition. The specific gravity of Ririwai biotite was determined as 2.4 .
\end{abstract}

Keywords: Ririwai biotite, SEM, EDX, drilling mud, yield point, morphology

\section{INTRODUCTION}

Drilling mud is a suspension fluid that is indispensable in well drilling. Drilling mud performs key roles in petroleum production [1], such as cooling and lubricating drilling tools, carrying and suspending cuttings, cleaning wellbore, minimizing fluid loss across permeable formation, and maintain the stability of the wellbore and formation [2-5]. The main functions of drilling fluids include providing hydrostatic pressure to prevent formation fluids from entering into the well bore, keeping the drill bit cool and clean during drilling. The drilling fluid used for a particular job is selected to avoid formation damage and to limit corrosion [6]. Water-based bentonite drilling fluid is widely used in the petroleum industry because of its cost effectiveness and being advantageous environmentally $[7,8]$. Water based drilling mud can be prepared using bentonitic clay precursor and other additives.

Bentonite is a clay mineral belonging to the montmorillonite mineral family. Montmorillonite structural architecture consists of an octahedral

\footnotetext{
${ }^{*}$ Corresponding author (Tel: +234 (0)806 598 4175)

Email addresses: nsalahudeen.cpe@buk.edu.ng (N. Salahudeen), ummarumaishanu@yahoo.com (U. Mohammed), mnyahya.cpe@buk.edu.ng (M. N. Yahya)
}

alumina layer sandwiched between two tetrahedral silica sheets. They are regarded as 1:2 category of clay [9]. Natural bentonites are either monovalent-cation based or divalent-cation based montmorillonites. The monovalent cation associated with natural bentonite mineral is majorly $\mathrm{Na}^{+}$while the associated divalent cation is majorly $\mathrm{Ca}^{2+}$. Natural bentonites can also exist with mixed interlayer cations; $\mathrm{Ca}^{2+} / \mathrm{Na}^{+}[10]$. Biotite is a $\mathrm{Fe}^{2+}$-rich phyllosilicate, it is a major constituent of rock and granite [11]. Its chemical formula can be represented as $\mathrm{K}(\mathrm{Mg}, \mathrm{Fe})_{3}\left(\mathrm{AlSi}_{3} \mathrm{O}_{10}\right)(\mathrm{OH}$, $\mathrm{F})_{2}$. The presence of weighting agent in drilling fluid stabilizes hydrostatic pressure in the borehole thereby minimizing fluid loss as a result of deposition of thick filter cake on the wall of the well, it also increases the penetration rate of the borehole [12]. The aim of this work is to determine the morphological and chemical characterization of Ririwai biotite and investigate its impact on the yield point of drilling mud when it is applied as weighting agent.

\section{MATERIALS AND METHODS}

\subsection{Materials}

The materials used include raw biotite mined from Ririwai Village, Tudun Wada Local Government Area of Kano State, Nigeria, commercial 
bentonite and distilled water. Apparatuses used include viscometer (Maker: Fann Model 35A), electronic compact scale (Maker: Kerro BL10001), mud stirrer, digital stop watch, beakers and measuring cylinder, spatula and Mixing bowl.

\subsection{Mud Preparation}

The drilling mud was prepared according to the API 13A standard. For every preparation $6 \%$ of drilling mud solid was applied in distilled water and was thoroughly mixed for about $30 \mathrm{~min}$ until a homogenous mixture was obtained. For $0 \%$ weighting agent formulation, the drilling mud sample was prepared by dissolving $30 \mathrm{~g}$ of commercial bentonite in $500 \mathrm{ml}$ of distilled water. The mixture was thoroughly mixed for about $30 \mathrm{~min}$ using a Hamilton Beach commercial mixer until the drilling mud becomes completely homogeneous. For a $10 \%$ weighting agent formulation, the above procedure was repeated but $10 \%$ of the initial bentonite $(3 \mathrm{~g})$ was substituted with Biotite. Therefore, the formation was $27 \mathrm{~g}$ bentonite plus $3 \mathrm{~g}$ biotite dissolved in $500 \mathrm{ml}$ distilled. Similarly for $20 \%-100 \%$ weighting agent formulations, the above procedure was repeated with biotite introduced as weighting agent at various weight percent ranging from $20 \%-100 \%$ at interval of $10 \%$.

\subsection{Yield Point Determination}

The mud sample prepared was poured into viscometer cup to the scribed mark. The viscometer cup was adjusted until the sleeve of the viscometer was into the mud unto the level indicated in the spindle. The viscometer knob was adjusted to obtain 300 and $600 \mathrm{rpm}$ dial readings. The dial reading of the various mud formulations at $600 \mathrm{rpm}$ was denoted as A. The dial reading of the various mud formulations at $300 \mathrm{rpm}$ was denoted as B. Therefore, the yield point of the various mud formulations (in $\mathrm{lb} / 100 \mathrm{ft}^{2}$ ) was determined by Eq. (1).

$$
\text { Yield point }=2 B-A
$$

\subsection{Specific Gravity}

Specific gravity of the weighting agent was measured using density bottle. The specific gravity was determined using Eq. (2).

$$
\text { Specific gravity }=\frac{\left(W_{2}-W_{1}\right)}{\left(W_{4}-W_{1}\right)-\left(W_{3}-W_{2}\right)}
$$

where, $W_{1}$ is weight of empty bottle, $W_{2}$ is weight of bottle + clay, $W_{3}$ is weight of bottle + clay + water and $W_{4}$ is weight of bottle + full water.

\subsection{Scanning Electron Microscopy (SEM) and Energy Dispersive X-ray (EDX)}

SEM and EDX analyses were carried out using PhenomWorld Scanning Electron Microscope; Prox, manufactured by Eindhoven the Neitherlands. The SEM machine was allowed to stabilize at about vacuum of $9 \times 10^{-5}$ torr. The solid was pretreated by pulverization and spurting. Few sample of the solid, about $20 \mathrm{mg}$ was mounted on the stub of a spurting machine to coat the solid surface with about $40 \mathrm{~nm}$ of gold. Then the spurted sample was placed in the SEM sample holder. Using the computer interface, magnification setting of $500 \times$ was made and images at different selected areas were collected. Similarly, at other magnification settings of $1000 \times$ and $1500 \times$ images at different selected areas were collected. Also using the computer interface EDX data of the sample was collected at about 1000 counts/s.

\section{6. $X$-ray Diffraction}

XRD patterns were recorded from Bragg's angle $(2 \theta)$ of $5^{\circ}$ to $705^{\circ}$; Rigaku Miniflex600, operated at continuous scanning, scanning speed of $55^{\circ} / \mathrm{min}$, generator settings of $10 \mathrm{~mA}$ and $40 \mathrm{kV}$, and $\mathrm{CuK} \alpha$ node material.

\section{RESULTS AND DISCUSSION}

Figure 1 shows the viscometer dial readings at 300 and $600 \mathrm{rpm}$ against weight percent of biotite weighting agent. For the viscometer spindle rotation of $600 \mathrm{rpm}$, it could be observed that a continuous trend of decrease in dial reading was observed with increase in weight percent of the weighting agent from $0-70 \mathrm{wt} \%$. Between weighting agent concentration of $70-90 \mathrm{wt} \%$ the dial reading was relatively constant at $4 \mathrm{lb} / 100$ $\mathrm{ft}^{2}$. At weighting agent concentration of $100 \mathrm{wt} \%$, the dial reading further dropped to $4 \mathrm{lb} / 100 \mathrm{ft}^{2}$. For the viscometer spindle rotation of $300 \mathrm{rpm}$, it could be observed that similar to the $600 \mathrm{rpm}$ reading a continuous trend of decrease in dial reading was observed with increase in weight percent of the weighting agent from $0-60 \mathrm{wt} \%$. Between $60-70 \mathrm{wt} \%$ weighting agent concentration the dial reading was constant at $2 \mathrm{lb} / 100 \mathrm{ft}^{2}$. Further from $70 \mathrm{wt} \%$ the dial reading decreased to 1 $\mathrm{lb} / 100 \mathrm{ft}^{2}$ at $80 \mathrm{wt} \%$ and remained constant between $80-100$ wt\%.

Figure 2 shows the mud yield point against weight percent of biotite weighting agent. It could be observed that the yield point of the drilling mud was constant at $2.0 \mathrm{lb} / 100 \mathrm{ft}^{2}$ for weighting agent composition of $0-30 \mathrm{wt} \%$. Between $30-50 \mathrm{wt} \%$ of weighting agent the yield point of the mud decreased steadily until it was $0.0 \mathrm{lb} / 100 \mathrm{ft}^{2}$ at 50 wt\% and above. It can be deduced that the rheological property of the mud was plastic for weighting agent composition of $0-30 \mathrm{wt} \%$. Above 30 wt\% the mud lost its plasticity and gradually became brittle. At weighting agent composition of of $50 \mathrm{wt} \%$ and above the mud was completely brittle. The region between $30-50 \mathrm{wt} \%$ could be seen as the transitional region between plastic and brittle behavior of the formulated mud. A drilling fluid formulation using weighting agent composition higher than $50 \mathrm{wt} \%$ will result into a poor petroleum production as a result of substantial pressure loss in the reservoir production line occasioned by presence of several local fracture fronts in the drilling mud. The brittle mud will further 


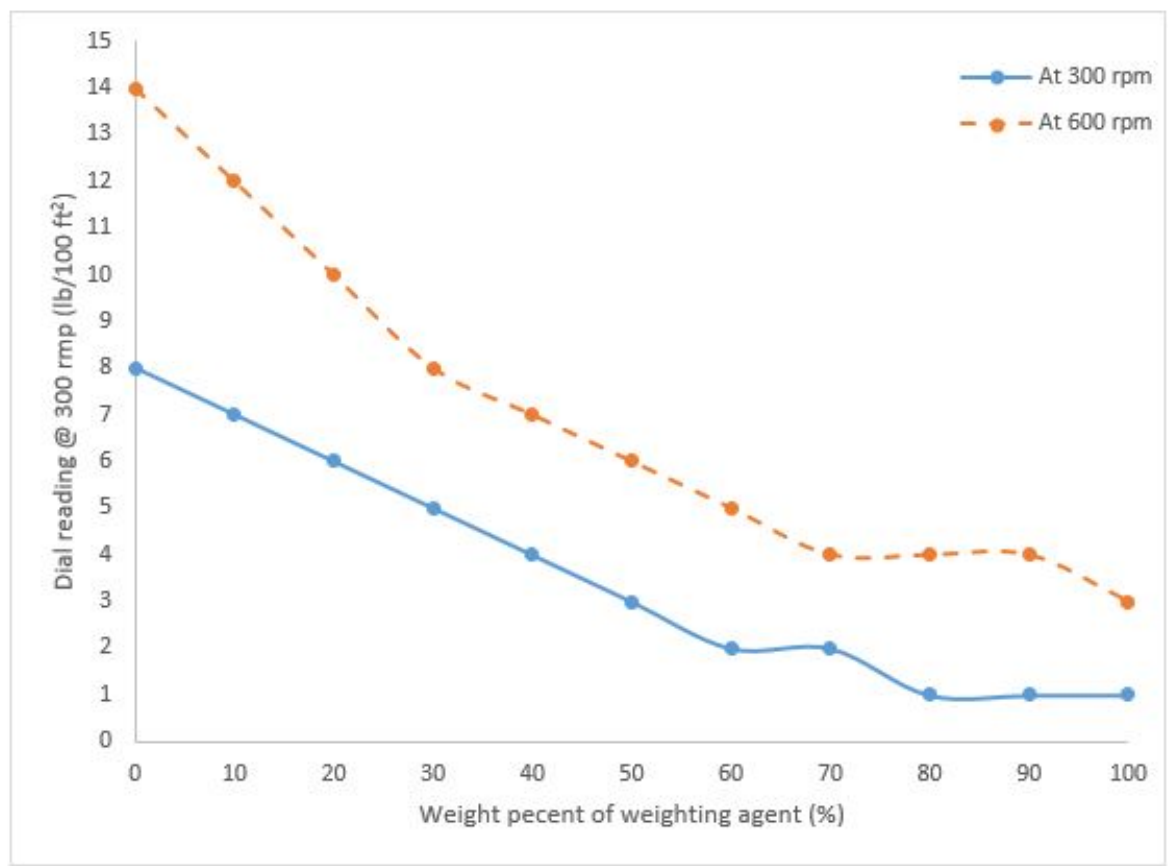

Figure 1: Viscometer dial reading at 300 and $600 \mathrm{rpm}$ against weight percent of weighting agent.

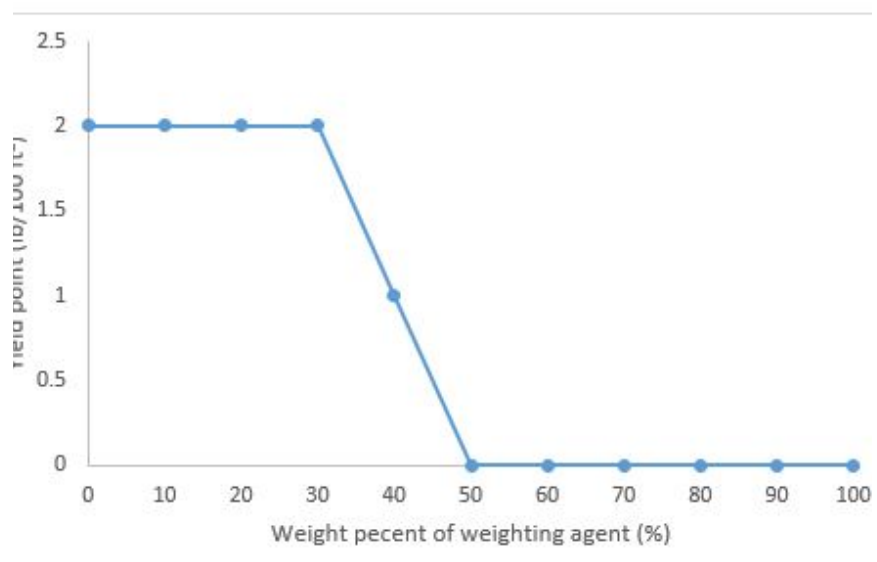

Figure 2: Mud yield point against weight percent of weighting agent.

reduce petroleum production by its abrasive impact on the walls of the production well.

Using Eq. (2), the specific gravity of the commercial bentonite was determined as 1.03 while that of the weighting agent was 2.40 . The local material used could be considered as a promising weighting agent as its specific gravity was 2.3 times the specific gravity of the commercial bentonite used. However, the specific gravity of the local material was relatively lower than the specific gravity of barite, a common weighting agent used for drilling muds which is reported to have average specific gravity of $4.4[13,14]$.

Figure 3 shows XRD patterns of the weighting agent used. It could be observed that the predominant mineral present in the material was biotite. The biotite phases were identified at $2 \theta$ values of $9^{\circ}, 24^{\circ}, 26.8^{\circ}$ and $36.7^{\circ}[15]$. Other minor phases present in the weighting agent were quartz and microcline which phases are indicated by $Q$ and M, respectively [13].

Figures $4 \mathrm{a}-4 \mathrm{c}$ show SEM images of commercial bentonite used for the water based drilling mud, at various magnifications. Figures $4 \mathrm{a}$ and $4 \mathrm{~b}$ are images at $500 \times$ and $1000 \times$ magnification, respectively. Although, Fig. 4b shows clearer particle distribution of the bentonite than Fig. 4a, both images show relatively even distribution of micro-particles of the bentonite having irregular sizes and shape. Figure 4c shows a micrograph of the bentonite at magnification of $1500 \times$. The micrograph is clearer as it reveals clearer details of the particles. It could be observed that the particles have clumpy morphology and irregular crystal shapes. The average particle size was estimated as $25 \mu \mathrm{m}$.

Figures 5 show SEM images of Ririwai biotite used as weighting agent in the prepared drilling mud, at various magnifications. Figures $5 \mathrm{a}$ and $5 \mathrm{~b}$ are images at $500 \times$ and $1000 \times$ magnification, respectively. Although, Fig. 5b shows clearer particle distribution of the bentonite than Fig. 5a, both images show uneven distribution of particles of the biotite having irregular sizes. Figure $5 \mathrm{c}$ shows a micrograph of the biotite at magnification of $1500 \times$. The micrograph is clearer as it reveals clearer details of the particles. It could be observed that the particles have sheet-like morphology and hexagonal crystal shape with some degree of crystal shape irregularity possibly due to high degree of crystal defects. The average particle size was estimated as $60 \mu \mathrm{m}$.

Table 1 presents the Energy dispersive X-ray (EDX) elemental analysis of Ririwai biotite and 


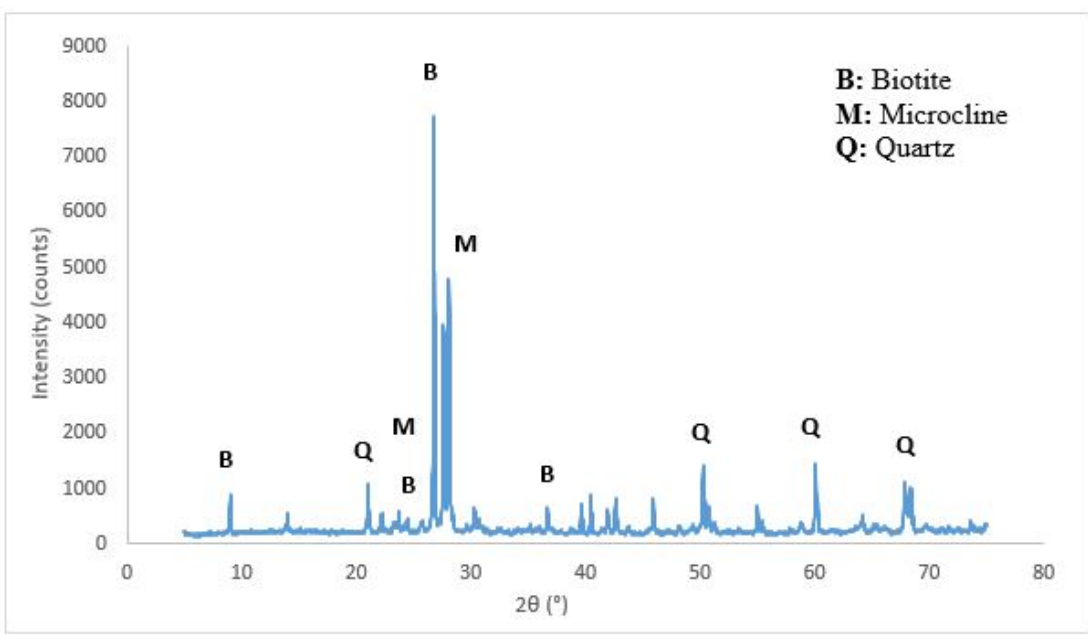

Figure 3: XRD patterns of Ririwai biotite used as weighting agent.

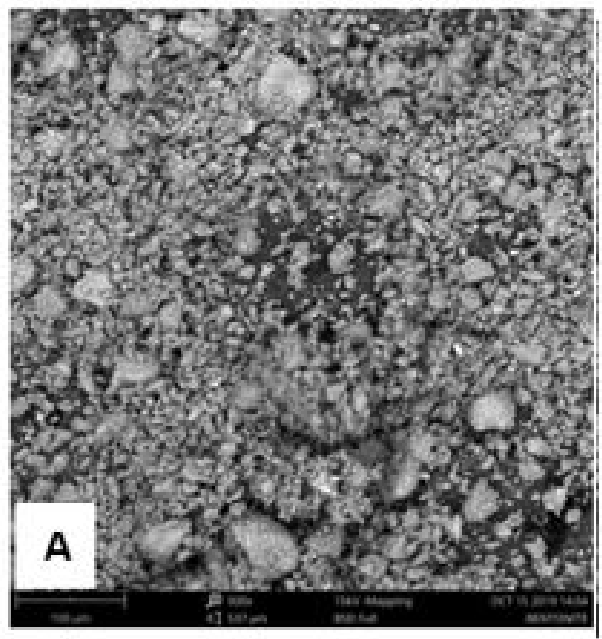

(a)

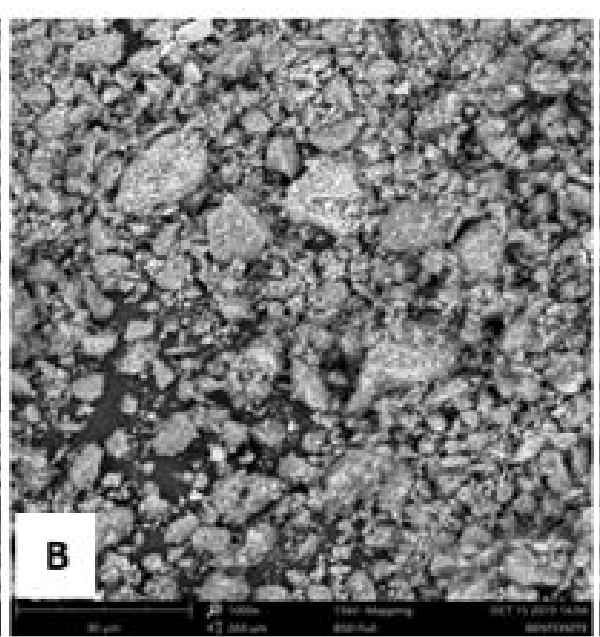

(b)

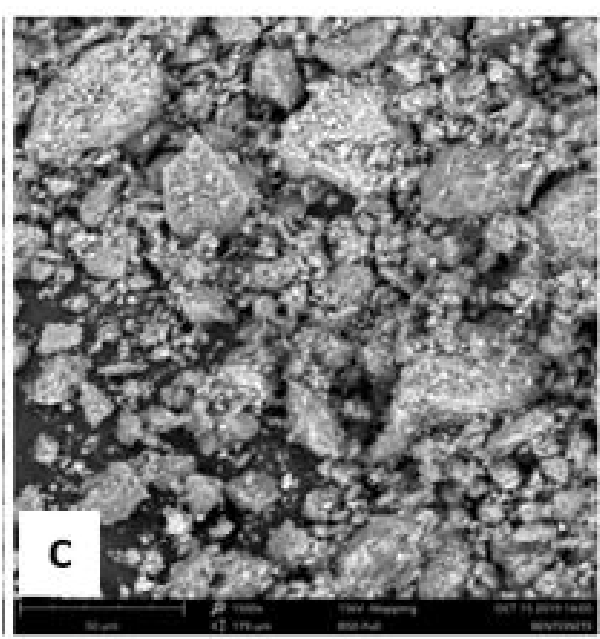

(c)

Figure 4: SEM images of commercial bentonite at magnifications of (a) 500x, (b) 1000x and (c) 1500x .

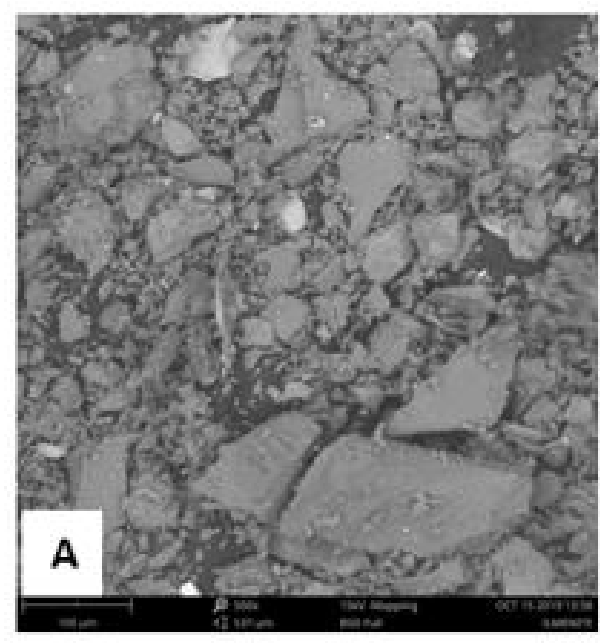

(a)

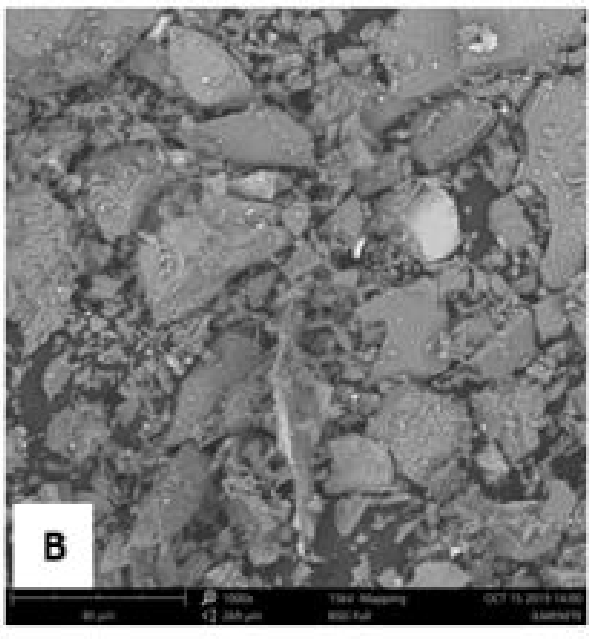

(b)

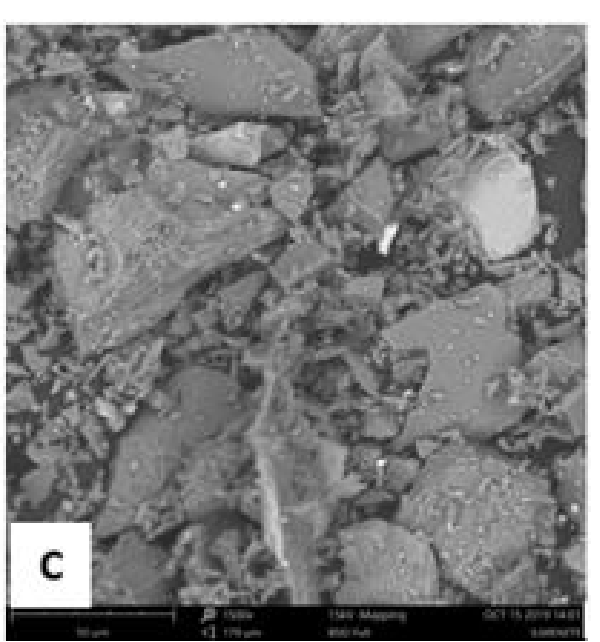

(c)

Figure 5: SEM images of Ririwai biotite at magnifications of (a) $500 \times$ (b) $1000 \times$ (c) $1500 \times$. 
Table 1: Energy dispersive X-ray (EDX) elemental analysis of Ririwai biotite and commercial bentonite.

\begin{tabular}{llc}
\hline $\begin{array}{l}\text { Elemental } \\
\text { composition }\end{array}$ & \multicolumn{2}{c}{ Composition $(w t \%)$} \\
\hline $\mathrm{Si}$ & 39.37 & Biotite \\
$\mathrm{Al}$ & 24.87 & 69.22 \\
$\mathrm{Fe}$ & 7.39 & 7.47 \\
$\mathrm{Ca}$ & 4.32 & 6.45 \\
$\mathrm{Ba}$ & 4.24 & 0.91 \\
$\mathrm{Ti}$ & 3.77 & $* \mathrm{ND}$ \\
$\mathrm{Nb}$ & 3.40 & 0.51 \\
$\mathrm{Ag}$ & 3.08 & 1.89 \\
$\mathrm{Mn}$ & 2.64 & 2.72 \\
$\mathrm{~K}$ & 1.92 & 0.39 \\
$\mathrm{~V}$ & 1.75 & 8.42 \\
$\mathrm{Cr}$ & 1.72 & 0.37 \\
$\mathrm{Mg}$ & 0.89 & $* \mathrm{ND}$ \\
$\mathrm{Na}$ & 0.63 & 0.27 \\
$\mathrm{TOTAL}$ & 99.99 & 1.36 \\
\hline
\end{tabular}

*ND: Not determined

the commercial bentonite used in the formation of drilling mud. The two materials are aluminosilicate minerals. Most of the constituent metals are in their oxide forms as it is known of all aluminosilicate minerals [16]. The dominant composition of the bentonite was silica which was present up to $39.37 \mathrm{wt} \%$ followed by alumina which was $24.87 \mathrm{wt} \%$. Therefore, the silicaalumina ratio of the bentonite was 1.58. The low silica alumina ratio of the bentonite indicates the dominating presence of montmorillonite mineral in the material. The elemental analysis of the commercial bentonite used in this study indicated that the bentonite contains both monovalent and divalent cations. The calcium oxide content was $4.32 \mathrm{wt} \%$ while the sodium oxide was 0.63 wt\%. The bentonite was a mixed interlayer cation based, but largely calcium based, meaning that the $\mathrm{Ca}^{2+}$ is the exchangeable interlayer cation in the 1:2 structural architecture of the montmorillonite mineral constituting the bentonite. The calcium cation dominance was seven times multiple of the sodium cation presence. The bentonite was rich in iron, barium, titanium, niobium, silver and manganese to the tone of $7.39,4.24,3.77,3.40$, 3.08 and $2.64 \mathrm{wt} \%$, respectively. These are likely to be majorly contributed by associated mixed mineral phases in the bentonite or chemical additives added to the processed bentonite to improve its rheological characteristic to make it suitable for drilling fluid application. In particular, the barium oxide of $4.24 \mathrm{wt} \%$ was likely due to presence of barite additive. Vanadium and chromium were present at 1.75 and $1.72 \mathrm{wt} \%$, respectively, they are likely due to presence of associated impurities. The potassium and magnesium compositions of 1.92 and $0.89 \mathrm{wt} \%$ were likely due to salt additives for enhancement of the rheology of the drilling mud.

The dominant chemical constituent of the biotite was silica having $69.22 \mathrm{wt} \%$ composition. The alumina composition was 7.47 wt\%. The

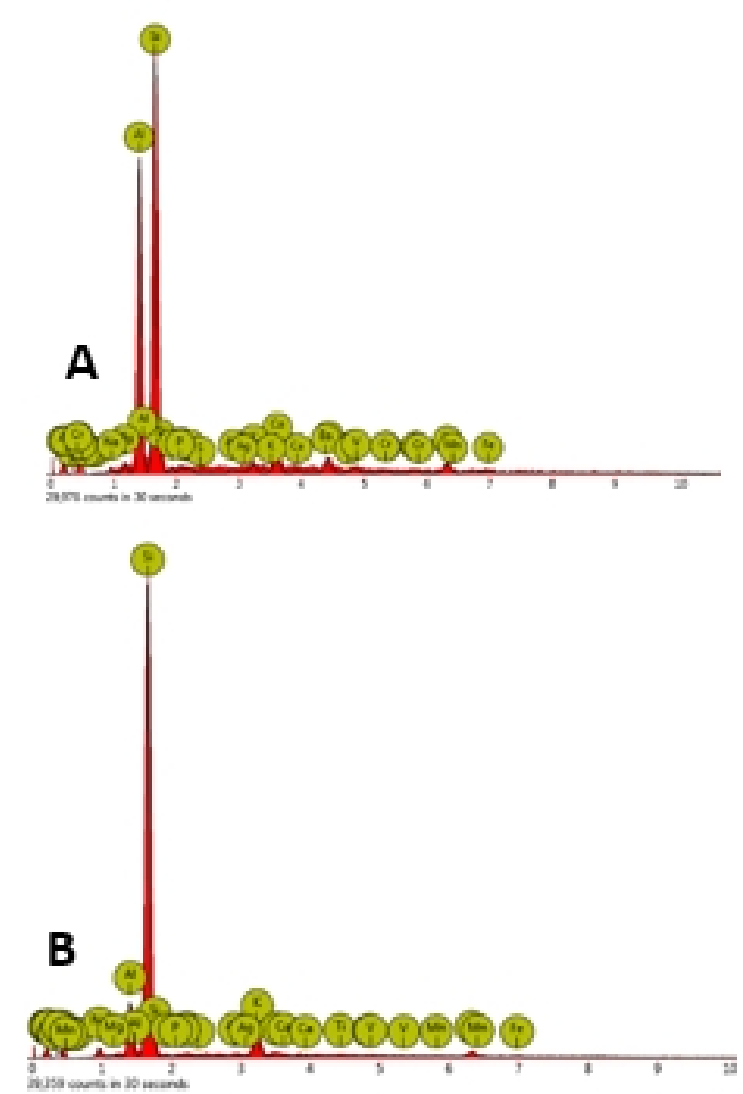

Figure 6: EDX elemental distribution mapping of (a) commercial bentonite (b) biotite .

silica-alumina ratio was very high, up to 9.3, making the mineral highly silicious. The high silica content was likely due to the presence of substantial quartz as shown in the X-ray diffractogram in Fig. 3, as quartz is simply a crystalline silica. The potasium oxide, magnesium oxide and iron oxide compositions of $8.42,0.27$ and 6.45 $\mathrm{wt} \%$, respectively are part of the structural framework of the biotite mineral. Other compositions such as calcium, titanium, niobium, silver, manganese, vanadium and sodium analyzed as 0.91 , $0.51,1.89,2.72,0.39,0.37$ and $1.36 \mathrm{wt} \%$, respectively were due to impurity associated with the biotite mineral, these are likely due to the microcline mineral identified as associated impurity phase in the X-ray diffractogram in Fig. 3.

Fig 6 shows the elemental distribution mapping of the energy dispersive X-ray (EDX) for; (a) the the commercial bentonite used and; (b) Ririwai biotite. The distribution mapping for the commercial bentonite was collected at 1000 counts/s while that of the biotite was collected at 1312 counts/s. It could be observed that the dominant peak in both was due to Si followed by $\mathrm{Al}$. This indicates that both minerals are alumino-silicate minerals as already established earlier.

\section{CONCLUSION}

Mineralogical analysis of the local material used showed that the dominant mineral phase in 
the local weighting material was biotite. Morphological analysis of the Ririwai biotite has shown that the mineral possesses a sheet-like morphology with hexagonal crystal shape and an estimated average particle size of $60 \mu \mathrm{m}$. SEM analysis of the commercial bentonite revealed that the mineral possesses clumpy morphology with irregular crystal shapes and an estimated average particle size of $25 \mu \mathrm{m}$. The chemical compositional analysis of the Ririwai biotite indicated that the material is a highly siliceous aluminosilicate mineral having a silica-alumina ratio of 9.3. Chemical compositional analysis of the commercial bentonite indicated that the material is an aluminosilicate mineral having a silica-alumina ratio of 1.58. The bentonite was a mixed interlayer cationbased possessing $\mathrm{Na}^{+}$monovalent exchangeable interlayer cation and $\mathrm{Ca}^{2+}$ divalent exchangeable interlayer cation. The divalent cation was predominant as the calcium oxide content was 4.32 wt\% while the sodium oxide was $0.63 \mathrm{wt} \%$. The yield point of the formulated drilling mud using Ririwai biotite weighting agent had yield point of $2.0 \mathrm{lb} / 100 \mathrm{ft}^{2}$ for formulation having $0-30$ wt\% weighting agent composition. Above $30 \mathrm{wt} \%$ the yield point decreased steadily until it was 0.0 $\mathrm{lb} / 100 \mathrm{ft}^{2}$ at $50 \mathrm{wt} \%$ weighting agent composition. The Mud formulated was plastic at weighting agent concentration (C) of $0 \leq \mathrm{C} \leq 30 \mathrm{wt} \%$ and this region corresponds to a yield point value of $2.0 \mathrm{lb} / 100 \mathrm{ft}^{2}$. At $30 \leq \mathrm{C}<50 \mathrm{wt} \%$ the mud displayed necking property with continuous drop in the yield point value. At $\mathrm{C} \geq 50 \mathrm{wt} \%$ the mud becomes brittle having yield point value of $0.0 \mathrm{lb} / 100$ $\mathrm{ft}^{2}$. The specific gravity of Ririwai biotite was 2.4 which was about $55 \%$ the average specific gravity of barite, a common weighting agent for drilling mud $[13,14]$. On the basis of its relative lower specific gravity, Ririwai biotite is not likely to serve as an excellent drilling mud weighting agent when compared to the common weighting agents like barite. Nonetheless, Ririwai biotite can be considered as a fair weighing agent on the basis of its moderate specific gravity which is 2.3 times the specific gravity of the commercial bentonite used.

\section{References}

[1] M. Du, P. Liu, P. Clode, J. Liu, B. Haq, and L. Y., "Impact of additives with opposing effects on the rheological properties of bentonite drilling mud: Flow, ageing, microstructure and preparation method," Journal of Petroleum Science and Engineering, vol. 192, pp. 1$10,2020$.

[2] S. Blkoor and K. Fattah, "The Influence of XC-Polymer on Drilling Fluid Filter Cake Properties and Formation Damage,"J. Petrol Environ. Biotechnol., vol. 4, no. 5, pp. 157-161, 2013.

[3] V. Kelessidis, C. Tsamantaki, A. Michalakis, G. Christidis, P. Makri, K. Papanicolaou, and A. Foscolos, "Greek lignites as additives for controlling filtration properties of water-bentonite suspensions at high temperatures," Fuel, vol. 86, pp. 7-8, 2007.

[4] V. Dmitry, C. Gabriel, R. Jay, T. Jason, D. Arvind, E. James, and M. James, "Graphene oxide as a highperformance fluid-loss-control additive in water-based drilling fluids," Acs Appl. Mater. Inter., vol. 4, no. 1, pp. 222-227, 2011.

[5] M. Li, Q. Wu, K. Song, Y. Qing, and Y. Wu, "Cellulose nanoparticles as modifiers for rheology and fluid loss in bentonite water-based fluids," Acs Appl. Mater. Inter., vol. 7, no. 8, pp. 5006-5016, 2015.

[6] W. Larry, "Petroleum engineering handbook," Volume II: Drilling Engineering, Society of Petroleum Engineers, USA, pp. 90-95, 2007.

[7] M. Barry, Y. Jung, J. Lee, T. Phuoc, and M. Chyu, "Fluid filtration and rheological properties of nanoparticle additive and intercalated clay hybrid bentonite drilling fluids," J. Petrol. Sci. Eng., vol. 127, pp. 338-346, 2007.

[8] V. Mahto and V. P. Sharma, "Rheological study of a water based oil well drilling fluid," J. Petrol. Sci. Eng., vol. 45 , no. 1 , pp. $123-128,2004$.

[9] L. Jianwei, J. Bohui, and Z. Yanhui, "Effect of pretreatment of bentonite with sodium and calcium ions on phosphate adsorption onto zirconium-modified bentonite," Journal of Environmental Management, vol. 217, no. 1, pp. 183-195, 2018.

[10] B. Sans, O. Güven, F. Ésenli, and M. Çelik, "Contribution of cations and layer charges in the smectite structure on zeta potential of ca-bentonites," Appl. Clay Sci., vol. 143 , pp. 415-421, 2017.

[11] A. W. Bray, L. Benning, S. Bonneville, and E. Oelkers, "Biotite surface chemistry as a function of aqueous fluid composition," Geochem Cosmochim, Acta, vol. 128, pp. 58-70, 2014.

[12] M. Abdou, A. Al-Sabagh, H. Ahmed, and A. Fadl, "Impact of barite and ilmenite mixture on enhancing the drilling mud weight," Egyptian Journal of Petroleum, vol. 27, pp. 955-967, 2018.

[13] M. AI-Awad and A. AI-Qasabi, "Characterization and Testing of Saudi Barite for Potential use in Drilling Operations," J. King Saud Univ., vol. 13, pp. 287-299, 2000.

[14] K. Khan, S. Khan, M. Saleem, and M. Ashraf, "Improvement of locally available raw bentonite for use as drilling mud," The Open Construction and Building Technology Journal, vol. 11, pp. 274-284, 2017.

[15] P. Chen, "Tables of key lines in $\mathrm{x}$ - ray powder diffraction patterns of minerals," Bloomington, Indiana, 1977.

[16] N. Salahudeen, A. Ahmed, A. Al-Muhtaseb, M. Dauda, S. Waziri, and B. Jibril, "Synthesis of Gamma Alumina from Kankara Kaolin Using a Novel Technique," Applied Clay Science, vol. 105, pp. 170-177, 2015. 